UDC 577.112

\title{
Apocynin attenuates motility and induces transition from sustained to transient EGF-dependent Akt activation in MCF-7 cells that overexpress adaptor protein Ruk/CIN85
}

\author{
A. V. Bazalii, L. B. Drobot, S. V. Komisarenko \\ Palladin Institute of Biochemistry, NAS of Ukraine \\ 9, Leontovicha Str., Kyiv, Ukraine, 01601 \\ bazalii@biochem.kiev.ua
}

\begin{abstract}
Aim. To study a possible involvement of NADPH oxidases in the control of cell motility and Akt signaling in the human breast adenocarcinoma MCF-7 cells that stably overexpress the full-length form of adaptor protein Ruk/CIN85. Methods. Cell motility was studied by a transwell migration assay. The dynamics of EGFinduced Akt activation was investigated by Western blot analysis. Results. It has been shown that apocynin, an inhibitor of the assembly of plasma membrane NADPH oxidases, substantially attenuates the motility of Ruk/CIN85 overexpressing MCF-7 cells (subclone G10) in comparison with the control cells. In addition, apocynin induced the transition from sustained to transient EGF-dependent Akt activation in G10 cells and did not influence transient Akt activation in the control cells. Conclusions. Data obtained can suggests that ROS produced by NADPH oxidases are signaling components, upstream to Akt kinase, that mediate the increased migratory potential of Ruk/CIN85-overexpressing MCF-7 cells.
\end{abstract}

Key w or d s: NADPH oxidases, apocynin, adaptor protein Ruk/CIN85, motility, EGF, Akt signaling.

\section{Introduction}

A large body of experimental evidence suggests that reactive oxygen species (ROS) at physiological concentrations function as signaling molecules to mediate various responses including the tumor cell proliferation, migration, invasion, and gene expression [1-3]. NADPH oxidases are a major source of ROS within cells required for space- and time-dependent control of redox signaling [4-6]. The localized production of $\mathrm{H}_{2} \mathrm{O}_{2}$ in the vicinity of specific substrates leads to their reversible oxidized modification and hence to the modulation of signaling responses $[6,7]$. It can be suggested that the adaptor/scaffold proteins consisting of domains and motifs involved in the intermolecular interactions could play key roles in the compartmentalization of ROS-mediated signal transduction as well as could influence its specificity, efficiency and dynamics $[8,9]$.

Our previous studies revealed that adaptor protein $\mathrm{Ruk} / \mathrm{CIN} 85$, which contains three SH3 domains in its structure, can interact with Pro-rich motifs of adaptor protein Tks4 $[10,11]$ functioning as an organizer subunit of NADPH-oxidase complex mediated by Nox1 $[12,13]$. Additionaly, it has been shown by us that the ROS production by human colorectal adenocarcinoma HT-29 cells is positively correlated with the Ruk/CIN85 expression [14]. Recently, we have demonstrated systemic multidirectional changes in mRNA levels for NOX1, NOX2, NOX5, DUOX2 and $\mathrm{p} 22^{\text {Phox }}$ in Ruk/CIN85-overexpressing human breast adenocarcinoma MCF-7 cells [15] characterized by increased malignant phenotype [16]. Using the expression vector encoding fluorescent sensor of hydrogen peroxide HyPer fused with

(C) 2016 A. V. Bazalii et al.; Published by the Institute of Molecular Biology and Genetics, NAS of Ukraine on behalf of Biopolymers and Cell.

This is an Open Access article distributed under the terms of the Creative Commons Attribution License (http://creativecommons.org/licenses/by/4.0/),

which permits unrestricted reuse, distribution, and reproduction in any medium, provided the original work is properly cited 
adaptor protein Ruk/CIN85 and live cell fluorescence microscopy, the co-localization of Ruk/CIN85 and $\mathrm{H}_{2} \mathrm{O}_{2}$ generation was shown to take place at the edges of certain vesicular structures in transiently transfected MCF-7 cells [17]. However, no data regarding the involvement of NADPH oxidases in the control of tumor cell motility and intracellular signaling depending on the levels of Ruk/CIN85 expression have been reported so far.

\section{Materials and methods}

\section{Cell cultute}

Cell line MCF-7 (human breast adenocarcinoma) stably transfected with an empty vector (control cells) and its subline G10 with Ruk/CIN85 overexpression [16] were maintained in DMEM $\left(\right.$ Gibco $\left.^{\circledR}\right)$ containing $10 \%$ fetal calf serum (FCS, HyClone), $2 \mathrm{mM}$ glutamine, $50 \mathrm{U} / \mathrm{ml}$ penicillin, $50 \mu \mathrm{g} / \mathrm{ml}$ streptomycin $\left(\mathrm{Gibco}^{\circledR}\right)$ at $37^{\circ} \mathrm{C}$ and $5 \% \mathrm{CO}_{2}$ in a humidified atmosphere. The cells were split 1:3-1:5 every 2-3 days at 70-80 \% confluency. Prior to the EGF treatment, the cells were cultured for $24 \mathrm{~h}$ in starvation medium (DMEM containing $0.1 \%$ FCS) in the absence or presence of $300 \mu \mathrm{M}$ apocynin (Aldrich). The cells were treated for $1,5,10$, or $30 \mathrm{~min}$ with either sterile phosphate-buffered saline (control) or EGF (100 ng/ml, Sigma).

\section{Protein preparation and Western blot analysis}

MCF-7 cells were scraped off in lysis buffer [50 mM Tris-HCI, pH 7.5, $150 \mathrm{mM} \mathrm{NaCI}, 1 \%$ Triton X-100, $1 \mathrm{mM}$ o-vanadate, $50 \mathrm{mM}$ NaF, $2 \mathrm{mM}$ EDTA, $1 \mathrm{mM}$ PMSF, complete inhibitor cocktail tablet (Roche)], mechanically triturated through a $1 \mathrm{ml}$ syringe, kept on ice for $20 \mathrm{~min}$ and centrifuged at $14000 \mathrm{~g}$ for 20 $\min$ at $4{ }^{\circ} \mathrm{C}$. After centrifugation of lysates, the protein content in supernatants was determined using a bicinchoninic acid protein assay kit (Pierce Biotechnology). Proteins (30 $\mu \mathrm{g}$ per sample) were separated by electrophoresis on $10 \%$ polyacrylamide gels and transferred to nitrocellulose membranes. The membranes were incubated with monoclonal anti-Ruk/CIN85 [17], anti-Akt (Cell Signaling) and anti-phospho-Akt
(Ser473) (Cell Signaling) antibodies overnight at $4^{\circ} \mathrm{C}$. Appropriate peroxidase-conjugated secondary antibodies (Sigma) were used at 1:3000 dilutions. The enhanced chemiluminescence kit (Amersham Pharmacia Biotech) was used for detection of the immunoreactive bands.

\section{Transwell migration assay}

The cell motility assay was performed essentially as described in [16] using 24-well cell culture inserts with $8 \mu \mathrm{m}$ pores (Greiner Bio-One). Where indicated, the cells were preincubated with $300 \mu \mathrm{M}$ apocynin for $24 \mathrm{~h} .3 \times 10^{4}$ cells were seeded on the upper wells of chambers in the presence of $0.1 \%$ serum and $300 \mu \mathrm{M}$ apocynin. The lower wells were filled with medium containing $5 \%$ FCS. After incubation for $12 \mathrm{~h}$, the cells that migrated out onto the lower surface of membranes were fixed in $4 \%$ paraformaldehyde. These cells were stained with $1 \%$ crystal violet and counted in five random fields (more than 100 cells were scored in each experiment).

\section{Statistics}

Statistical analysis was carried out using SPSS 12.0 software. Paired and unpaired Student's t-tests were performed and the difference was considered to be significant when the $\mathrm{P}$-value was $\leq 0.05$.

\section{Results and Discussion}

Many reports of last decade provide an evidence that ROS, produced by NADPH oxidases in mammalian cells in response to the activation of membrane receptors, play important roles in carcinogenesis [13]. Redox-sensitive signaling associated with NADPH oxidases has been shown to occur in different subcellular compartments involved in the control of tumor cells migration and invasion [2, 18]. The adaptor/scaffold proteins of modular structure not only determine the formation and localization of signaling complexes [8] but also control the specificity, efficiency and amplitude of signal propagation [9]. Adaptor/scaffold protein Ruk/CIN85 containing three SH3 domains, proline-rich region and C-terminal coiled-coil domain was shown to be a 
platform for signaling complexes formation involved in the control of fundamental cellular and signaling events as well as carcinogenesis [19, 20]. By analyzing samples from breast cancer patients with invasive breast adenocarcinomas, we found high levels of Ruk/CIN85 especially in lymph node metastases and intravascular tumor emboli [16]. Stable expression of Ruk/CIN85 in weakly invasive breast adenocarcinoma MCF-7 cells was followed by their reduced growth rate, decreased cell adhesion, enhanced anchorage-independent growth and increased motility. The stimulation of Ruk/CIN85overexpressing MCF-7 cells with EGF led to a more rapid and prolonged activation of Src, Akt and ERK1/2 while the treatment with Src inhibitor PP2 and PI3K inhibitor LY294002 abolished the Ruk/ CIN85-dependent changes in cell motility [16]. Taking into account our data regarding the direct physical interaction of Ruk/CIN85 with the organizer subunit Tks4 of NOX1-containing NADPH oxidase complex $[10,11]$, a positive correlation between the level of Ruk/CIN85 expression and the ROS production in tumor cells [14, and our unpublished data], co-localization of adaptor protein and $\mathrm{H}_{2} \mathrm{O}_{2}$ generation at the edges of certain vesicular structures in MCF-7 cells transiently transfected with the plasmid encoding fluorescent sensor of hydrogen peroxide Hyper fused with Ruk/CIN85 [17], the potential of Ruk/CIN85 to differentially influence $N O X$ genes expression in MCF-7 cells stably overexpressing different levels of Ruk/CIN85 [15], it was the aim of this study to investigate a possible involvement of NADPH oxidases in the control of cell motility and Akt signaling depending on the Ruk/CIN85 expression levels in MCF-7 cells. For this purpose we used apocynin, which is considered to be one of the most specific inhibitor of NADPH oxidases, which blocks the assembly of the active enzyme complex [21]. In accordance with our previous results [16], we demonstrated that the motility of MCF-7 G10 cells with a high level of Ruk/CIN85 overexpression was significantly higher than that of control cells (Fig. 1A). The treatment of G10 cells with apocynin resulted in the suppression of their

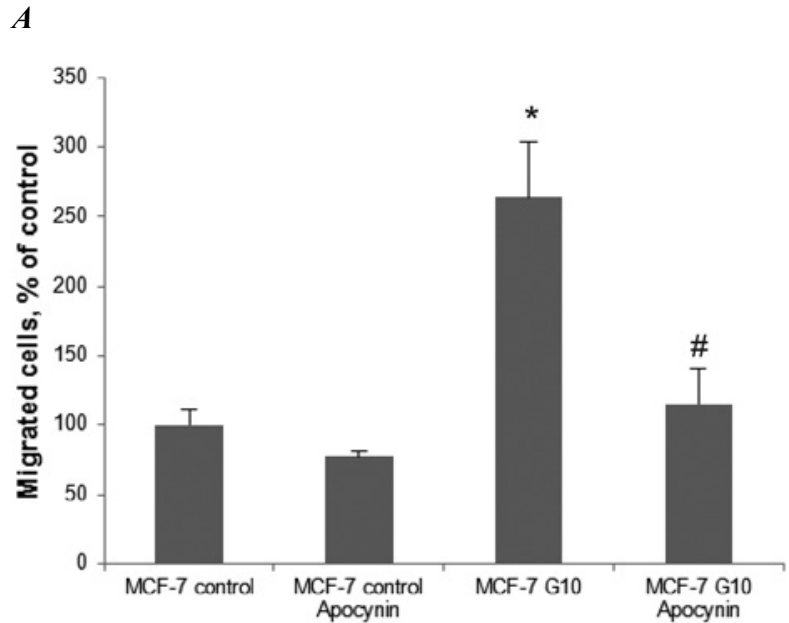

$\boldsymbol{B}$

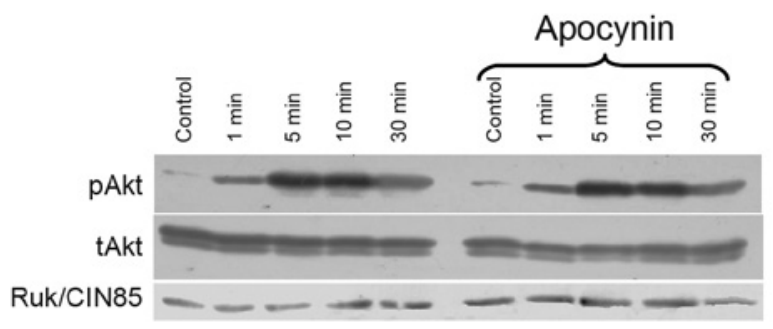

C

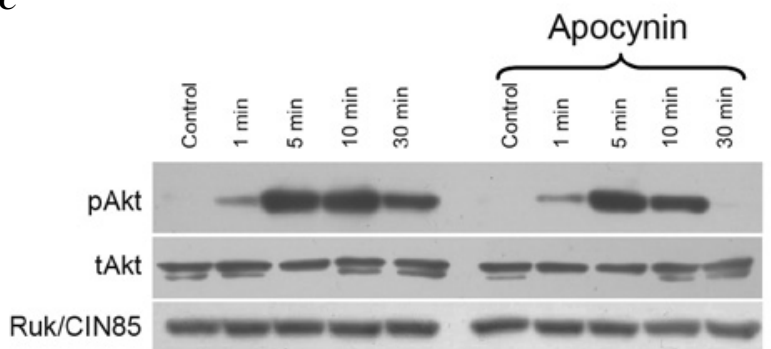

Fig. 1. Apocynin attenuates motility and induces the transition from sustained to transient EGF-dependent Akt activation in human breast adenocarcinoma MCF-7 cells that overexpress adaptor protein Ruk/CIN85. A. The transwell migration assay was used to study the motility of control (MCF-7 control) and Ruk/ CIN85-overexpressing (MCF-7 G10) cells. The number of migrated control cells was set equal to $100 \%$. Data are mean \pm SEM of three independent experiments. ${ }^{*} \mathrm{P} \leq 0.05$ compared with control. \#P $\leq 0.05$ compared with MCF-7 G10. B, C. Western blotting of pAkt, tAkt and Ruk/CIN85 in lysates of control MCF-7 cells (B) and Ruk/CIN85-overexprerssing MCF-7 G10 cells $(\mathrm{C})$ treated with EGF $(100 \mathrm{ng} / \mathrm{mL})$ for indicated periods of time. The representative blots of three independent experiments are shown. 
migratory potential to the level of control cells. As can be seen from Fig.C, EGF induced more potent activation of Akt kinase up to $30 \mathrm{~min}$ of stimulation in comparison with the dynamics of Akt activity characteristic of control cells (Fig. 1B). The pretreatment of G10 cells with apocynin resulted in the disappearance of a signal for pAkt at 30 min while in control cells any changes in the Akt activity caused by apocynin were not observed (Fig. $1 B, 1 C$ ). These data allow us to conclude that in Ruk/CIN85overexpressing MCF-7 cells apocynin induces the transition from sustained to transient EGF-dependent Akt activation. Several studies demonstrated that ROS, such as $\mathrm{H}_{2} \mathrm{O}_{2}$, can modulate the Akt activity in various cell types through different mechanisms [for review see 7] thereby influencing the cell migration and invasion [22]. To elucidate the molecular mechanisms involved in the Ruk/CIN85-mediated regulation of NADPH oxidases and ROS production, the control of Akt signaling and biological responses, further studies are necessary

\section{Conclusions}

The data obtained can suggest that ROS produced by NADPH oxidases are signaling components upstream to Akt kinase that possibly mediate the increased migratory potential of Ruk/CIN85-overexpressing MCF-7 cells.

\section{Funding}

This work was partially supported by bilateral grant between National Academy of Sciences (NAS) of Ukraine and Russian Fund for Basic Research (RFBR) - 2012.

\section{REFERENCES}

1. Meitzler JL, Antony S, Wu Y, Juhasz A, Liu H, Jiang G, Lu J, Roy K, Doroshow JH. NADPH oxidases: a perspective on reactive oxygen species production in tumor biology. Antioxid Redox Signal. 2014;20(17):2873-89.

2. Díaz B, Courtneidge $S A$. Redox signaling at invasive microdomains in cancer cells. Free Radic Biol Med. 2012;52(2):247-56.

3. Roy K, Wu Y, Meitzler JL, Juhasz A, Liu H, Jiang G, Lu J, Antony $S$, Doroshow JH. NADPH oxidases and cancer. Clin Sci (Lond). 2015;128(12):863-75.
4. Lambeth $J D$. NOX enzymes and the biology of reactive oxygen. Nat Rev Immunol. 2004;4(3):181-9.

5. Katsuyama $M$. NOX/NADPH oxidase, the superoxide-generating enzyme: its transcriptional regulation and physiological roles. J Pharmacol Sci. 2010;114(2):134-46.

6. Finkel $T$. Reactive oxygen species and signal transduction. IUBMB Life. 2001;52(1-2):3-6.

7. Drobot LB, Samoylenko AA, Vorotnikov AV, Tyurin-Kuzmin PA, Bazalii AV, Kietzmann T, Tkachuk VA, Komisarenko SV. Reactive oxygen species in signal transduction. Ukr Biokhim Zh. 2013;85(6):209-17.

8. Pawson T. Dynamic control of signaling by modular adaptor proteins. Curr Opin Cell Biol. 2007;19(2):112-6.

9. Levchenko A, BruckJ, Sternberg PW. Scaffold proteins may biphasically affect the levels of mitogen-activated protein kinase signaling and reduce its threshold properties. Proc Natl Acad Sci U S A. 2000;97(11):5818-23.

10. Havrylov S, Rzhepetskyy Y, Malinowska A, Drobot L, Redowicz MJ. Proteins recruited by SH3 domains of Ruk/CIN85 adaptor identified by LC-MS/MS. Proteome Sci. 2009;7:21.

11. Bazalii AV, Samoylenko AA, Petukhov DM, Rynditch AV, Redowicz M-J, Drobot LB. Interaction between adaptor proteins Ruk/CIN85 and Tks4 in normal and tumor cells of different tissue origins. Biopolym Cell. 2014; 30(1): 37-41.

12. Gianni D, Diaz B, Taulet N, Fowler B, Courtneidge SA, Bokoch GM. Novel p47(phox)-related organizers regulate localized NADPH oxidase 1 (Nox1) activity. Sci Signal. 2009;2(88):ra54.

13. Gianni D, DerMardirossian C, Bokoch GM. Direct interaction between Tks proteins and the N-terminal proline-rich region (PRR) of NoxA1 mediates Nox1-dependent ROS generation. Eur J Cell Biol. 2011;90(2-3):164-71.

14. Samoylenko AA, Byts NV, Pasichnyk GV, Kozlova NV, Bazalii $A V$, Gerashchenko DS, Shandrenko $S G$, Vorotnikov $A V$, Kietzmann T, Komisarenko SV, Drobot LB. Recombinant lentivirus-mediated silencing of adaptor protein Ruk/CIN85 expression influences biological responses of tumor cells. Biotechnologia Acta. 2013; 6(4): 182-9.

15. Bazalii AV, Horak IR, Pasichnyk GV, Komisarenko SV, Drobot LB. Transcriptional regulation of NOX genes expression in human breast adenocarcinoma MCF-7 cells is modulated by adaptor protein Ruk. CIN85. Ukr. Biochem. J. 2016; 88(1): 119-25.

16. Samoylenko A, Vynnytska-Myronovska B, Byts N, Kozlova $N$, Basaraba O, Pasichnyk G, Palyvoda K, Bobak Y, Barska M, Mayevska O, Rzhepetsky Y, Shuvayeva H, Lyzogubov V, Usenko V, Savran V, Volodko N, Buchman V, Kietzmann T, Drobot $L$. Increased levels of the HER1 adaptor protein Rukl/CIN85 contribute to breast cancer malignancy. Carcinogenesis. 2012;33(10):1976-84.

17. Bazalii AV, Vorotnikov AV, Tiurin-Kuzmin PA, Tkachuk VA, Komisarenko SV, Drobot LB. Recombinant fluorescent sensor of hydrogen peroxide fused with adaptor protein Ruk. 
CIN85: desining of expression vector and functional characterization. Biotechnologia Acta. 2015; 8(5): 19-26.

18. Ushio-Fukai M. Compartmentalization of redox signaling through NADPH oxidase-derived ROS. Antioxid Redox Signal. 2009;11(6):1289-99.

19. Dikic I. CIN85/CMS family of adaptor molecules. FEBS Lett. 2002;529(1):110-5.

20. Havrylov $S$, Redowicz MJ, Buchman VL. Emerging roles of Ruk/CIN85 in vesicle-mediated transport, adhesion, migration and malignancy. Traffic. 2010;11(6):721-31.

21. Stefanska J, Pawliczak R. Apocynin: molecular aptitudes. Mediators Inflamm. 2008;2008:106507.

22. McAuliffe PF, Meric-Bernstam F, Mills GB, Gonzalez-Angulo $A M$. Deciphering the role of PI3K/Akt/mTOR pathway in breast cancer biology and pathogenesis. Clin Breast Cancer. 2010;10 Suppl 3:S59-65.

\section{Апоцинін пригнічує рухливість і індукує перехід від тривалої до тимчасової EGF-індукованої активації Akt в клітинах МCF-7 3 надекспресісю адаптерного протеїну Ruk/CIN85}

\section{А. В. Базалій, Л. Б. Дробот, С. В. Комісаренко}

Мета. 3'ясувати можливе залучення NADPH оксидаз до контролю рухливості клітин i Akt-залежного сигнального шляху в аденокарциномних клітинах грудної залози людини лінії MCF-7, що стабільно надекспресують адаптерний протеїн Ruk/CIN85. Методи. Для аналізу рухливості клітин використовували модифіковану камеру Бойдена. Динаміку EGFіндукованої активації Akt досліджували Вестерн-блот аналізом. Результати. Було показано, що апоцинін, інгібітор збирання мембранних NADPH оксидаз, значно пригнічує рухливість клітин MCF-7, що надекспресують Ruk/CIN85 (субклон G10) у порівнянні $з$ контрольними клітинами. Крім цього, апоцинін індукував перехід від тривалої до тимчасової EGFіндукованої активації Akt у G10 клітинах і не впливав на тимчасову активацію Akt у контрольних клітинах. Висновки. Отримані дані дозволяють припустити, що АФК, продукти NADPH оксидаз, є сигнальними компонентами, розташовани- ми вище від кінази Akt, які опосередковують підвищений міграційний потенціал клітин MCF-7 3 надекспресією Ruk/ CIN85.

Кл юч о в і с л о в а: NADPH оксидази, апоцинін, адаптерний протеїн Ruk/CIN85, рухливість, EGF, Akt-залежне сигналювання.

\section{Апоцинин угнетает подвижность и индуцирует переход от длительной к временной EGF-индуцированной активации Akt в клетках MCF-7 со сверхэкспрессией адаптерного белка Ruk/CIN85}

\section{А. В. Базалий, Л. Б. Дробот, С. В. Комисаренко}

Цель. Выяснить возможное вовлечение NADPH оксидаз в контроль подвижности клеток и Akt-зависимого сигнального пути в аденокарциномных клетках грудной железы человека линии MCF-7, которые стабильно сверхэкспрессируют адаптерный белок Ruk/CIN85. Методы. Для анализа подвижности клеток использовали модифицированную камеру Бойдена. Динамику EGF-индуцированной активации Akt исследовали Вестерн-блот анализом. Результаты. Было показано, что апоцинин, ингибитор сборки мембранных NADPH оксидаз, значительно угнетает подвижность клеток MCF-7, которые сверхэкспрессируют Ruk/CIN85 (субклон G10) по сравнению с контрольными клетками. Кроме этого, апоцинин индуцировал переход от длительной к временной EGF-индуцированной активации Akt в G10 клетках и не влиял на временную активацию Akt в контрольных клетках. Выводы. Полученные данные позволяют предположить, что АФК, продукты NADPH оксидаз, являются сигнальными компонентами, расположенными выше от киназы Akt, которые опосредуют повышенный миграционный потенциал клеток MCF-7 со сверхэкспрессией Ruk/CIN85.

Кл юч е в ы е с л о в а: NADPH оксидазы, апоцинин, адаптерный белок Ruk/CIN85, подвижность, EGF, Akt-зависимая сигнализация. 